\title{
RETENSI REKAM MEDIS DALAM UPAYA EFISIENSI RAK PENYIMPANAN
}

\author{
Edy Susanto*11), Irmawati, Adhani Windari, Ivana Putri Risyanti, Yogi Teguh Prakoso, \\ Johninda Aulia Akbar, Rizky Febri Nugroho, Agustin Ira Krisnanita, Bernadeta Riski \\ Kristiyani
}

\author{
1)Jurusan Rekam Medis dan Informasi Kesehatan ; Poltekkes Kemenkes Semarang \\ Jl. Tirto Agung ; Pedalangan ; Banyumanik; Semarang ; Jawa Tengah ; Indonesia
}

\begin{abstract}
Abstrak
Rekam medis pasien rawat inap di rumah sakit wajib disimpan sekurang-kurangnya untuk jangka waktu 5 (lima) tahun tehitung dari tanggal terakhir pasien berobat atau dipulangkan (Permenkes 269/Menkes/Per/III/2008 dalam bab IV pasal 8. Berdasarkan studi pendahuluan tanggal 12 desember 2016, permasalahan yang terjadi dalam pengelolaan rekam medis di RSUD Tugurejo Semarang khususnya retensi rekam medis adalah terakhir pelaksanaan retensi dokumen rekam medis pada tahun 2011 hal ini disebabkan kurangnya pengetahuan SDM dalam tata cara retensi dokumen rekam medis. Sehingga tim pengabmas dari jurusan RMIK melaksanakan pengabmas di rumah sakit tersebut dengan tujuan meningkatnya pengetahuan pegawai unit kerja rekam medis tentang retensi rekam medis dan terlaksananya retensi rekam medis untuk optimalisasi pemanfaatan ruangan penyimpanan rekam medis. Metode yang dilakukan adalah melalui Pendidikan Kesehatan : paparan teori tentang retensi rekam medis (kebijakan, alur, prosedur), simulasi, pendampingan dan konsultasi kemudian monitoring dan evaluasi dalam retensi tersebut dilaksanakan selama 20 hari dengan melibatkan 5 mahasiswa dengan rata-rata perhari rekam medis yang diretensi sejumlah 180 dari rekam medis in aktif 6.364. pengabdian kepada masyarakat berkaitan dengan retensi rekam medis ini menumbuhkan pengetahuan kepada petugas filing melalui pemaparan dan pendampingan pelaksanaan retensi.
\end{abstract}

Kata kunci: Rekam Medis ; Retensi ; RSUD Tugurejo Semarang

\begin{abstract}
[MEDICAL RECORD RETENCE FOR EFFICIENCY OF THE STORAGE RACK] Medical records of hospitalized patients must be kept at least for a period of 5 (five) years calculated from the last date the patient was treated or returned (Permenkes 269 / Menkes / Per / III / 2008 in chapter IV article 8 . Based on the preliminary study date December 12, 2016, the problems that occurred in the management of medical records at Tugurejo Hospital Semarang especially medical record retention were the last implementation of medical record document retention in 2011 due to a lack of knowledge of HR in the procedures for retention of medical records. The service at the hospital was aimed at increasing the knowledge of employees of the medical record work unit on medical record retention and the implementation of medical record retention to optimize the utilization of medical record storage space.The method used was through Health Education: exposure to theories about medical record retention (policy, flow, procedure), simulation, support and consultations then monitoring and evaluation in the retention was carried out for 20 days involving 5 students with an average of medical records which were retained 180 days from active medical records 6,364. community service related to medical record retention fosters knowledge to filing officers through exposure and assistance in implementing retention.
\end{abstract}

Keywords: Medical Record ; Retension ; RSUD Tugurejo Semarang

*) Correspondence author (Edy Susantoi)

E-mail: edy.jrr@gmail.com 


\section{Pendahuluan}

Rekam medis pasien rawat inap di rumah sakit wajib disimpan sekurang-kurangnya untuk jangka waktu 5 (lima) tahun tehitung dari tanggal terakhir pasien berobat atau dipulangkan(Permenkes 269/ Menkes/ Per/ III/ 2008 dalam bab IV pasal 8. Permasalahan yang terjadi dalam pengelolaan rekam medis di RSUD Tugurejo Semarang khususnya retensi dokumen rekam medis adalah terakhir pelaksanaan retensi dokumen rekam medis pada tahun 2011 hal ini disebabkan kurangnya pengetahuan SDM dalam tata cara retensi dokumen rekam medis. Menumpuknya berkas rekam medis baik berkas aktif maupun inaktif mengakibatkan ruangan penyimpanan rekam medis penuh dengan berkas rekam medis dan tidak mampu lagi menyimpan berkas rekam medis baru. RSUD Tugurejo Semarang baru satu kali melakukan retensi dokumen rekam medis.

Sesuai dengan UU Nomor 20 Tahun 2003 tentang Sistem Pendidikan Nasional, dimana perguruan tinggi berkewajiban menyelenggarakan Tri Dharma Perguruan Tinggi, yaitu pendidikan, penelitian, dan pengabdian kepada masyarakat. Salah satu dari Tri Dharma Perguruan Tinggi tersebut, yaitu pengabdian kepada masyarakat memiliki peran yang sangat penting terhadap pembangunan nasional di era globalisasi ini. Poltekkes Kemenkes Semarang, khususnya Jurusan Rekam Medis dan Informasi Kesehatan memberikan sumbangsihnya kepada masyarakat melalui kegiatan pengabdian kepada masyarakat yang dilakukan oleh civitas akademika di lingkungan Poltekkes Kemenkes Semarang terutama dalam bidang kesehatan, khususnya di bidang pengelolaan rekam medis di sarana pelayanan kesehatan.

Jurusan Rekam Medis dan Informasi Kesehatan telah melaksanakan kegiatan pengabdian kepada masyarakat dalam bentuk memberikan sosialisasi, pendampingan, konsultansi, dan simulasi dalam retensi dokumen rekam medis. Dengan kegiatan pengabdian kepada masyarakat ini, diharapkan mampu membantu kegiatan retensi dokumen rekam medis RSUD Tugurejo Semarang serta mampu memisahkan antara berkas rekam medis aktif dan inaktif di RSUD Tugurejo Semarang dan dapat menyediakan tempat bagi berkas rekam medis aktif sehingga pelayanan rekam medis dapat berjalan dengan baik dan dihasilkan informasi kesehatan yang berkualitas.

\section{Metode}

Metode penelitian yang digunakan sebagai berikut :

- Pendidikan Kesehatan

Pendidikan kesehatan dilakukan melalui memberikan pendidikan kepada pegawai rekam medis di RSUD Tugurejo Semarang tentang pengetahuan dan tata cara retensi dokumen rekam medis.

- Simulasi/ Praktik Lapangan

Praktik lapangan dilakukan dengan melakukan kegiatan retensi secara langsung dokumen rekam medis

- Pendampingan dan Konsultansi

Pendampingan dan konsultansi dilakukan pada saat mendampingi pegawai rekam medis dalam melaksanakan kegiatan retensi dokumen rekam medis

- Monitoring dan Evaluasi

Melakukan monitoring perkembangan kegiatan retensi di RSUD Tugurejo. Evaluasi dilaksanakan dengan membandingkan sistem penyimpanan sebelum dan sesudah kegiatan pengabmas. Monitoring dan evaluasi dilaksanakan setiap akhir bulan selama 3 bulan mulai September-November 2017.

- Finalisasi

Finalisasi merupakan tahap penyusunan laporan dan publikasi hasil pengabdian kepada masyarakat.

\section{Hasil dan Pembahasan}

Hasil Petugas rekam medis bagian filing di RSUD Tugurejo Semarang terdapat 13 petugas di bagian filing, tugas pokok di bagian filing adalah sebagai berikut:

Tabel 1 Uraian Tugas Petugas Filing

\begin{tabular}{lll}
\hline No & Uraian Tugas & Jumlah Petugas \\
\hline $\mathbf{1}$ & $\begin{array}{l}\text { Distribusi rekam } \\
\text { medis }\end{array}$ & 4 orang \\
\hline $\mathbf{2}$ & $\begin{array}{l}\text { Melacak rekam } \\
\text { medis yang salah } \\
\text { letak }\end{array}$ & 1 orang \\
\hline $\mathbf{3}$ & $\begin{array}{l}\text { Melaksanakan } \\
\text { retensi }\end{array}$ & 4 orang \\
\hline $\mathbf{4}$ & $\begin{array}{l}\text { Menyimpan rekam } \\
\text { medis in aktif }\end{array}$ & 2 orang \\
\hline $\mathbf{5}$ & $\begin{array}{l}\text { Melaksanakan } \\
\text { pemusnahan }\end{array}$ & 2 orang \\
\hline & Jumlah & 13 orang \\
\hline & Petugas penyimpanan rekam medis di
\end{tabular}


RSUD Tugurejo Semarang tidak semuanya berlatar belakang pendidikan Rekam Medis sehingga belum semuanya memahami mengenai retensi dan pemusnahan rekam medis.Pengabdian kepada masyarakat tentang retensi di RSUD Tugurejo Semarang ini kami telah melaksanakan paparan tentang proses retensi agar lebih efektif dan efisien.

Pelaksanaan retensi di RSUD Tugurejo Semarang dengan cara di pisahkan dari aktif ke inaktif berdasarkan tanggal terakhir pasien datang berobat yaitu jangka waktu 5 tahun (tahun terakhir berkunjung tahun 2012), melihat kunjungan terakhir pasien pada rekam medis, dipilah kemudian disusun sesuai dengan system penomoran TDF (terminal digit filing), setiap satu bendel rekam medis per tahun, memindahkan rekam medis inaktif ke rak inaktif. Kemudian dilakukan pemilahan formulir yang harus disimpan selamanya (tidak boleh dimusnahkan), langkah terakhir adalah pemusnahan rekam medis.

Tim pada pengabmas berhasil memilah rekam medis tersebut selama 20 hari dengan rata-rata melakukan retensi sejumlah 180 rekam medis dari total rekam medis yang in aktif selama 5 tahun terakhir.

Permasalahan yang ada adalah rekam medis inaktif sudah sangat menumpuk, pemilahan rekam medis hanya dilakukan oleh 2 orang staf retensi.Tata cara pemindahan berkas rekam medis aktif menjadi berkas rekam medis inaktif yang telah dilaksanakan oleh Tim Pengabmas dan Petugas retensi di RSUD Tugurejo yaitu :

a. Dilihat dari tanggal kunjungan terakhir

b. Setelah 5 (lima) tahun dari kunjungan terakhir tersebut berkas dipisahkan di ruang lain/terpisah dari berkas RM in aktif

c. Berkas rekam medis inaktif dikelompokkan sesuai dengan tahun terakhir kunjungan

Lembar rekam medis yang dipilah:

a. Ringkasan masuk dan keluar

b. Resume

c. Lembar operasi

d. Identifikasi bayi

e. Lembar persetujuan

f. Lembar kematian

Optimalisasi pemanfaatan ruang penyimpanan rekam medis.

Tabel 2 Jumlah Kunjungan Rawat Inap

\begin{tabular}{llll}
\hline \multicolumn{1}{c}{ Uraian } & $\mathbf{2 0 1 4}$ & $\mathbf{2 0 1 5}$ & $\mathbf{2 0 1 6}$ \\
\hline $\begin{array}{l}\text { Jml } \\
\text { Kunjungan }\end{array}$ & 26.364 & 28.512 & 29.265 \\
\hline
\end{tabular}

Seiring dengan bertambahnya jumlah pasien, maka bertambah pula jumlah dokumen rekam medis yang membutuhkan tempat penyimpanan rekam medis. Akhirnya rak penyimpanan rekam medis menjadi penuh jika tidak setiap hari dilaksanakan retensi dokumen rekam medis.

Kegiatan pengabmas telah melaksanakan penyusutan rekam medis yang aktif dan inaktif, kemudian memisahkannya dalam ruangan yang berbeda. Rekam medis pasien yang sudah 5 tahun (mulai 2012) tidak berobat kembali ke RSUD Tugurejo maka dianggap rekam medis inaktif. Berkas inaktif disusun secara Terminal Digit Filing pada ruang khusus rekam medis inaktif. rak penyimpanan rekam medis aktif dan inaktif terpisah, sehingga rak penyimpanan rekam medis aktif tidak terlalu penuh.

\section{Simpulan dan Saran}

Kesimpulan Tidak seluruh rekam medis di RSUD Tugurejo telah dilakukan retensi pada rekam medis in aktif oleh tim pengabmas karena keterbatasan waktu sehingga dilakukan sampai dengan bulan November 2017 dengan tetap melakukan monitoring dan evaluasi kepada petugas filing.

Retensi rekam medis mengurangi pemenuhan rak penyimpanan RSUD Tugurejo sehingga retensi perlu dilakukan secara berkala

\section{Ucapan Terima Kasih}

Terima kasih kepada Direktur Poltekkes Kemenkes Semarang, DIPA Poltekkes Kemenkes Semarang yang telah mendanai pengabmas ini, Tim penyusun pengabmas dan semua pihak yang terlibat dalam pengabmas ini..

\section{Daftar Pustaka}

Gemala.R. (2012). Pedoman Manajemen Informasi Kesehatan di sarana pelayanan kesehatan. Jakarta: Penerbit Universitas Jakarta

Mathis R.L dan Jackson J.H.(2002). Manajemen Sumber Daya Manusia.Jakarta : Salemba Empat

National Center for Health Statistics. 2008. International Classification of Disease, Tenth Revision (ICD-10). Diunduh : 23 Februari 2016

Internet : http://www.cdc.gov/nchs/about $\angle$ major/dvc/icd10des.htm.

Notoatmodjo, S. (2012). Metodologi Penelitian Kesehatan. Jakarta: Rineka Cipta 
Peraturan Menteri Kesehatan Republik Indonesia No. 269/Menkes/SK/III/2008 tentang Rekam Medis. 2008. Jakarta: Menkes RI

Peraturan Menteri Kesehatan Republik Indonesia No. 290/Menkes /Per/III/2008 tentang Persetujuan Tindakan Kedokteran. 2008. Jakarta: Menkes RI

Undang-undang Republik Indonesia Nomor 36 Tahun 2009 tentang Kesehatan

Undang-undang Republik Indonesia Nomor 36 Tahun 2014 tentang Tenaga Kesehatan

Wawan, A dan M, Dewi. (2011). Teori $\mathcal{E}$ Pengukuran Pengetahuan, Sikap, dan
PerilakuManusia. Yogyakarta: Nuha Medika World Health Organization. (2004). International Statistical Classification od Dissease and Related Health Problems Tenth Revision Volume 2 second edition. Geneva: World Health Organization

www.indonesian-publichealth.com, tentang Unsur-Unsur Managemen diakses pada tanggal 27 Februari 2016

www.hakayuci.com tentang Sistem kodefikasi, diakses pada tanggal 2 Maret 2016 